Global Journal of Business and Social Science Review

Journal homepage: http://gatrenterprise.com/GATRJournals/index.html

\title{
The Flip Classroom Learning on Design Student's Performance: An Analysis
}

\author{
MaheshChandra Babu Jampala* \\ Manipal University Jaipur, Dehmi Kalan, Near GVK Toll Plaza, Jaipur-Ajmer Expressway, 303007, Jaipur, Rajasthan, India.
}

\begin{abstract}
Objective - The objective of this research paper is to examine whether flipped learning would improve the performance of the 3rd year undergraduate design students compared to the traditional classroom learning.

Methodology/Technique - The performance of the students was assessed based on the parameters: communication skills, understanding of the concepts, teamwork, critical thinking, sharing the data, exploration of concepts, creative outcomes and engaging the problems. Students were provided different tools, case studies, video presentations and foundational concepts. The experimentation was conducted before and after implementation of flipped classroom.

Findings - The study revealed that final marks were gradually increased and nearly $80 \%$ students were satisfied with this way of learning. It was also observed that $82 \%$ students improved the communication skills, improved the critical thinking and helps to solve problems by themselves and started exploring new concepts. The study also focuses on the challenges on the adaptation of flipped learning among students and teachers.

Novelty - The use of the flipped classroom is one of the most emerging new media technology in the university.

Type of Paper: Empirical
\end{abstract}

Keywords: New Media Technology, Flipped learning, Performance, Self-learning, Classroom teaching.

JEL Classification: D83, I29, L82, L89.

\section{Introduction}

Education is one the vibrant sectors in India. In ancient times, India has the system of Gurukula Education where anyone can go to the house of teachers and requested to be taught. If accepted by the teacher, the student has to stay at teacher's home and learn. In the modern and developing India, students want to learn from any place and want to get a quality education. Many universities in India have started implementing the different technologies to make classroom teaching more effective. The Indian education sector has slowly implemented technology in the classroom. Technology has gradually changed the learning into the personalized form. Technology helps to make the tailoring education more powerful to each student's academic strength and weaknesses and optimal pace of learning and it also helps in blended learning which combines both traditional, teacher to student learning with technology based instruction. Many various disciplines (management, engineering, design, humanities and many more) are taught by using a blending learning concept.

\footnotetext{
Paper Info: Revised: September 8, 2016

Accepted: October 5, 2016

* Corresponding author:

E-mail: jampalamahesh@gmail.com

Affiliation: Faculty of Design, Manipal University Jaipur, India
} 
Design education is one of the key sectors in India. Developing countries like India is a large market and at the same unique as well. Markets vary in cultures, traditions, religions, customers, food, dressing and so on. Presently design industry is growing at a fast pace so do the Design Education System.

The Indian Design Education System offers diverse program choices at all levels, such as certificate, diploma, under graduate and post graduate programs which additionally includes programs like architecture, interior design, fashion, graphic design, animation, industrial design, retail and jewellery designing. In order to make these programs more interactive and collaborative, many Universities and Design Institutions have changed their teaching pedagogy by using different New Media Technologies.

According to the India Design Report by Confederation of Indian Industry, Design education has seen a tremendous growth in the last 7 years. Earlier, the design education landscape was characterized by Government supported institutions only, which were rare in numbers for a country as large as India. Now the awareness has flown to the higher education also. Many universities have started introduction of design disciplines.

In order to manage up with this number of student's intake and effective learning, many universities and institutions are taking innovative steps to make the teacher - student learning collaborative and learning centric. Many teachers are using different new media technologies for increasing collaborative skills to teach students. Various new media technologies are being used in classroom teaching, for example, 3D printing technologies, Badges, Massive Open Online Courses, Social Networking, Telepresence Technology, flipped classroom and much more.

The objective of this research paper is to examine whether flipped classroom technology would improve the performance of the 3rd year undergraduate design students compared to the traditional classroom learning. The performance of the students was assessed based on the parameters: communication skills, understanding of the concepts, team work, critical thinking, sharing the data, exploration of concepts, creative outcomes and engaging the problems. Students were provided different tools, case studies, video presentations and foundational concepts. The experimentation was conducted before and after implementation of Flipped classroom learning.

\section{Review of Literature}

According to the article in the Flipped learning network (2014), Flipped classroom is defined as "Flipped classroom learning is a pedagogical approach in which direct instruction moves from the group learning space to the individual learning space, and the resulting group space is transformed into a dynamic, interactive learning environment where the educator guides students as they apply concepts and engage creatively in the subject matter." The four pillars of the flipped classroom learning are F-Flexible environment, L-Learning curve, IIntentional content and P-Professional educator. Flexible environment means when and where the students learn. Kathleen Fulton (2012) listed the advantages of the flipped learning; firstly, students can learn at their own pace, secondly, students can easily do the "homework" in class which gives teachers better understanding into student problems and learning outcomes; thirdly, teachers can more easily modify and update the curriculum and deliver it to students at time; fourthly, classroom time can be used more efficiently and productively; fifthly, teachers using the method report seeing increased levels of student performance, interest, and engagement; sixthly, learning theory enhances the new approaches; and lastly flipped learning uses the technology which is essential for the present learning scenario. According it the National Center for Case Study teaching in Science listserv it was found that students spend more time in the authenticated research, students can watch the lectures anytime and anywhere and students can actively participate in the learning process.

Many universities in India have started using the flipped classroom teaching. Leading business schools and medical schools have slowly started using the flipped classroom in their teaching pedagogy. Slowly this culture is shifted to the other disciplines. 


\section{Research Methodology}

The study is to analyze the effect of the flipped classroom technology on the students' performance. The nature of the study is conceptual. The approach of the research is quantitative in nature. The research is empirical and experimental research. Empirical research is the research which is based on the observation and the phenomenon which drive knowledge from the actual experience of the theory. While outlining the hypotheses a central research questions were analyzed:

- What are the present New Media Technologies used in the Design Education in India?

- Is flipped classroom technology is used in Design Education?

- How the flip classroom will be helpful for the Design students?

Based on these central research questions, objectives of the research were framed:

- To find the effect performance of the design students after using flipped classroom technology.

- Based on the objectives of the research, the hypotheses were framed.

- H10 - There is no effect of flipped classroom technology on design student performance.

- H1a - There is an effect of flipped classroom technology on design student performance.

\subsection{Sample Design}

The target population is the design students in the Programme of the applied art of the Manipal University Jaipur, Jaipur. For conducting the experimental research, the sample was 30 students. For selecting a sample, random probability sampling technique was used.

\subsection{Data Collection}

The primary data is collected for the experimental research. A set of structured questionnaire was developed for measuring the performance of the design students before and after using flipped learning technology. For framing the questionnaire, unstructured interviews were conducted among the students. The questions asked were:

- How do you feel when teacher follows the traditional classroom teaching?

- Do you feel engaged in traditional classroom teaching?

- How is the communication between student and teacher?

- Did you understand the concepts well?

Based on the above questionnaires, the variable identified for measuring the performance of the students; effective communication, easy to understand the concepts, increases the team work capabilities, engage in making, sharing and collaborating with other students, improve creative outcomes, exploring the new concepts in depth and marks of students. The questionnaire was framed on the 5-point linked scale where the scale ranging from strongly agree to strongly disagree.

\subsection{Analytical Methods}

To test the hypotheses, SPSS software was used. The reliability analysis was done by using the Cronbach's alpha. This test is mainly used when there are multiple Likert questions in the questionnaire which determines the scale is reliable. 
Table 1: Cronbach's alpha and internal consistency

\begin{tabular}{|c|c|}
\hline Cronbach's alpha & Internal consistency \\
\hline$\alpha \geq 0.9$ & Excellent \\
\hline $0.7 \leq \alpha<0.8$ & Good \\
\hline $0.6 \leq \alpha<0.7$ & Acceptable \\
\hline $0.5 \leq \alpha<0.6$ & Ok acceptable \\
\hline$\alpha<0.5$ & Unacceptable \\
\hline
\end{tabular}

The Cronbach's alpha value is 0.672 , which is acceptable for the research.

For before and after analysis, paired sample t-test analyzes the before and after situations, when samples are matched paired. In this study paired sample t-test was used to analyze effect of flipped learning on the performance of the students.

\section{Analysis and Interpretation}

In this study, an experimental research was conducted on design students of Manipal University Jaipur. The University was established in the year 2011 in the Pink City, Jaipur, Capital of Rajasthan, India. The University has total approximately 5000 students and around 300 faculties in all disciplines. The university has five major faculties. A total of 30 undergraduate students each applied art Faculty of Design were considered for the research from the Manipal University Jaipur. The experimentation was conducted before and after the implementation of the flipped learning. Students were provided with the videos, reference materials before coming to the class. Teachers have also provided the specific topic and a list of materials for experimentation. The duration of the experimentation was for six months. The results were analyzed based on the performance of the students.

Table 2 Performance of the students before/after using flipped classroom technology (Part A)

\begin{tabular}{|c|c|c|c|c|c|c|c|c|c|}
\hline \multirow{2}{*}{$\begin{array}{c}\text { Performance of the students } \\
\text { before/after using flipped } \\
\text { learning }\end{array}$} & \multicolumn{8}{|c|}{$\begin{array}{c}\text { Indicators of Performance Measurement } \\
\text { Communication } \\
\text { With Faculty }\end{array}$} & \multicolumn{2}{c|}{$\begin{array}{c}\text { Easy to } \\
\text { understand }\end{array}$} & $\begin{array}{c}\text { Increases the } \\
\text { team work }\end{array}$ & $\begin{array}{c}\text { Increases the } \\
\text { critical } \\
\text { thinking }\end{array}$ \\
\cline { 3 - 11 } & & $\mathbf{N}$ & $\mathbf{\%}$ & $\mathbf{N}$ & $\mathbf{\%}$ & $\mathbf{N}$ & $\mathbf{\%}$ & $\mathbf{N}$ & $\mathbf{\%}$ \\
\hline \multirow{2}{*}{$\begin{array}{c}\text { Strongly Not } \\
\text { Satisfied }\end{array}$} & Before & 0 & 0 & 15 & 50.0 & 0 & 0 & 2 & 6.7 \\
\cline { 2 - 11 } & After & 0 & 0 & 0 & 0 & 0 & 0 & 0 & 0 \\
\hline \multirow{2}{*}{ Not Satisfied } & Before & 2 & 6.7 & 10 & 33.3 & 25 & 83.3 & 22 & 73.3 \\
\cline { 2 - 11 } & After & 0 & 0 & 1 & 3.3 & 0 & 0 & 0 & 0 \\
\hline \multirow{2}{*}{ Neutral } & Before & 19 & 63.3 & 5 & 16.7 & 4 & 13.3 & 6 & 20.0 \\
\cline { 2 - 11 } & After & 2 & 6.7 & 2 & 6.7 & 4 & 13.3 & 6 & 20.0 \\
\hline \multirow{2}{*}{ Satisfied } & Before & 9 & 30.0 & 0 & 0 & 1 & 3.3 & 0 & 0 \\
\cline { 2 - 11 } & After & 17 & 56.7 & 18 & 60.0 & 20 & 66.7 & 16 & 53.3 \\
\hline \multirow{2}{*}{ Strongly Satisfied } & Before & 0 & 0 & 0 & 0 & 0 & 0 & 0 & 0 \\
\cline { 2 - 10 } & After & 11 & 36.7 & 9 & 30.0 & 6 & 20.0 & 8 & 26.7 \\
\hline
\end{tabular}


Table 3 Performance of the students before/after using flipped classroom technology (Part B)

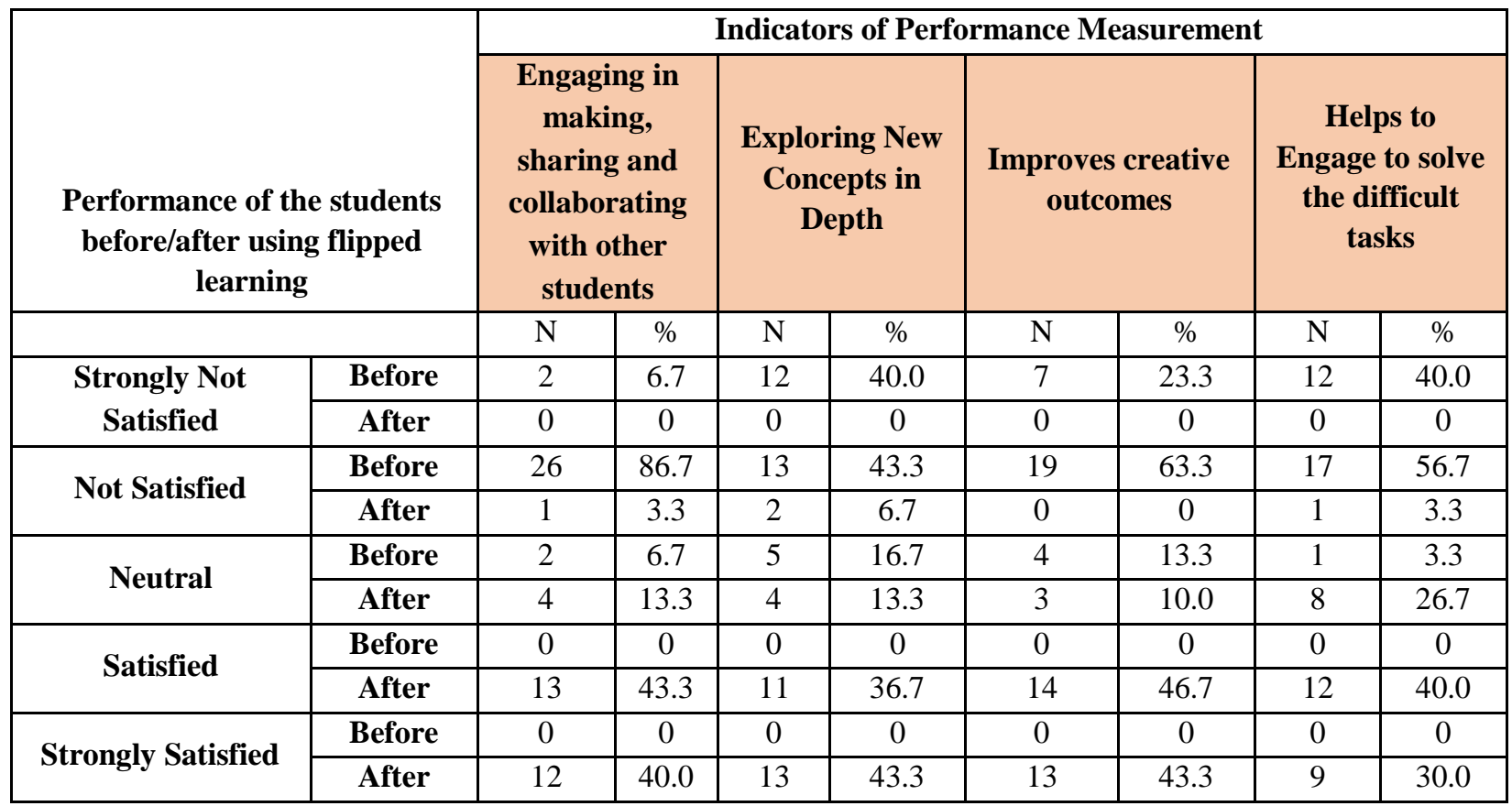

It observed after continuous monitoring, the majority of students (43.3\%) were satisfied and (50\%) strongly satisfied that after the implementation of the flipped classroom, effective communication with the teachers have increased. As students were more involved in the subject, understanding of the subject was easy for the students, 63.3\% students were satisfied that teamwork with the classmates was increased and 50\% students and 36.7\% students were satisfied and strongly satisfied that critical thinking has increased after the implementation of the flipped classroom. It was observed that the majority of the students $(93.3 \%)$ were engaged in making, sharing and collaborating of the information with other students (Table 3) and students (53.3\%) are satisfied and 36.7\% students are strongly satisfied that they started exploring the new concepts in depth which increases creative outcomes and helps to solve the complicated difficult tasks.

\subsection{Statistical interpretation}

The study has used Paired sample t-test to analyse the effect of flipped learning on the performance of students. Paired sample t-test analyses the before and after situations. Here as per the sample data, t-test is chosen to compare the performance of the undergraduate students of the Faculty of Design before and after implementation of flipped learning in the classroom.

H1o:- Flipped Learning will have no impact on student performance.

H1a:- Flipped Learning will have an impact on student performance. 
Table 4: Paired Sample T-Test on the performance of the undergraduate students of Applied Arts before and after implementation of flipped learning in the classroom.

\begin{tabular}{|c|c|c|c|c|c|c|c|c|c|}
\hline \multicolumn{10}{|c|}{ Paired Samples Statistics \& Correlation } \\
\hline \multirow[b]{3}{*}{ Pair 1} & Variables & Mean & Stc & \multicolumn{2}{|c|}{ Std. Deviation } & $\begin{array}{l}\text { td.Error } \\
\text { Mean }\end{array}$ & \multicolumn{2}{|c|}{ Correlation } & Sig. \\
\hline & Effective Communication With Faculty - Before & 2.73 & 30 & .521 & & .095 & \multirow{2}{*}{\multicolumn{2}{|c|}{-.162}} & \\
\hline & Effective Communication With Faculty - After & 4.43 & 30 & .626 & & .114 & & & .392 \\
\hline \multirow{2}{*}{ Pair 2} & Easy to understand-Before & 2.53 & 30 & .571 & & .104 & \multirow{2}{*}{\multicolumn{2}{|c|}{.193}} & 308 \\
\hline & Easy to understand-After & 4.37 & 30 & .669 & & .122 & & & .500 \\
\hline \multirow{2}{*}{ Pair 3} & $\begin{array}{l}\text { Increases the team work and effective work in groups } \\
\text {-Before }\end{array}$ & 2.30 & 30 & .466 & & .085 & \multirow{2}{*}{\multicolumn{2}{|c|}{.134}} & \multirow{2}{*}{.480} \\
\hline & $\begin{array}{l}\text { Increases the team work and effective work in groups } \\
\text { - After }\end{array}$ & 4.10 & 30 & .607 & & .111 & & & \\
\hline \multirow{2}{*}{ Pair 4} & $\begin{array}{l}\text { Using technology tools increases the critical thinking- } \\
\text { Before }\end{array}$ & 1.97 & 30 & .556 & & .102 & \multirow{2}{*}{\multicolumn{2}{|c|}{.478}} & \multirow{2}{*}{.008} \\
\hline & $\begin{array}{l}\text { Using technology tools increases the critical thinking- } \\
\text { After }\end{array}$ & 4.23 & 30 & .679 & & .124 & & & \\
\hline \multirow{2}{*}{ Pair 5} & $\begin{array}{l}\text { Engaging in making, sharing and collaborating with } \\
\text { other students before }\end{array}$ & 1.97 & 30 & .718 & & .131 & \multirow{2}{*}{\multicolumn{2}{|c|}{-.043}} & \multirow{2}{*}{.820} \\
\hline & $\begin{array}{l}\text { Engaging in making, sharing and collaborating with } \\
\text { other students After }\end{array}$ & 4.43 & 30 & .626 & & .114 & & & \\
\hline \multirow{2}{*}{ Pair 6} & Improves creative outcomes Before & 2.07 & 30 & .740 & & .135 & \multirow{2}{*}{\multicolumn{2}{|c|}{.169}} & \multirow{2}{*}{.373} \\
\hline & Improves creative outcomes After & 4.47 & 30 & .571 & & .104 & & & \\
\hline \multirow{2}{*}{ Pair 7} & Helps to Engage to solve the difficult tasks Before & 1.63 & 30 & .718 & & .131 & \multirow{2}{*}{\multicolumn{2}{|c|}{.120}} & \multirow{2}{*}{.527} \\
\hline & Helps to Engage to solve the difficult tasks After & 4.23 & 30 & .626 & & .114 & & & \\
\hline \multirow{2}{*}{ Pair 8} & Exploring new concept in depth Before & 1.73 & 30 & .691 & & .126 & \multirow{2}{*}{\multicolumn{2}{|c|}{-.078}} & \multirow{2}{*}{.683} \\
\hline & Exploring new concepts in depth After & 4.23 & 30 & .728 & & .133 & & & \\
\hline \multicolumn{10}{|c|}{ Paired Samples Test } \\
\hline & & Mean & $\begin{array}{c}\text { Std. } \\
\text { Deviation }\end{array}$ & $\begin{array}{c}\text { Std. } \\
\text { Error } \\
\text { Mean }\end{array}$ & \begin{tabular}{|} 
ces \\
95 \\
Confi \\
Interva \\
Diffe \\
Lower
\end{tabular} & $\begin{array}{l}5 \% \\
\text { fidence } \\
\text { val of the } \\
\text { erence } \\
\text { r Upper }\end{array}$ & $\mathrm{t}$ & df & $\begin{array}{l}\text { Sig. }(2- \\
\text { tailed })\end{array}$ \\
\hline Pair 1 & $\begin{array}{l}\text { Effective Communication With Faculty - Before } \\
\text { Effective Communication With Faculty - After }\end{array}$ & -1.700 & .877 & .160 & -2.027 & $7 \mid-1.373$ & -10.618 & 29 & .000 \\
\hline Pair 2 & $\begin{array}{l}\text { Easy to understand - Before - Easy to understand - } \\
\text { After }\end{array}$ & -1.833 & .791 & .145 & -2.129 & \begin{tabular}{l|l|l}
9 & -1.538
\end{tabular} & -12.687 & 29 & .000 \\
\hline Pair 3 & $\begin{array}{l}\text { Increases the team work and effective work in groups - } \\
\text { Before Increases the team work and effective work in } \\
\text { groups - After }\end{array}$ & -1.800 & .714 & .130 & -2.067 & $7 \mid-1.533$ & -13.801 & 29 & .000 \\
\hline Pair 4 & $\begin{array}{l}\text { Using technology tools increases the critical thinking- } \\
\text { Before - Using technology tools increases the critical } \\
\text { thinking- After }\end{array}$ & -2.267 & .640 & .117 & -2.506 & $5-2.028$ & -19.408 & 29 & .000 \\
\hline Pair 5 & $\begin{array}{l}\text { Engaging in making, sharing and collaborating with } \\
\text { other students before } \\
\text { Engaging in making, sharing and collaborating with } \\
\text { other students After }\end{array}$ & -2.467 & .973 & .178 & -2.830 & \begin{tabular}{l|l|l}
0 & -2.103
\end{tabular} & -13.882 & 29 & .000 \\
\hline Pair 6 & \begin{tabular}{|l} 
Improves creative outcomes Before \\
Improves creative outcomes After
\end{tabular} & -2.400 & .855 & .156 & -2.719 & \begin{tabular}{l|l|}
9 & -2.081
\end{tabular} & -15.375 & 29 & .000 \\
\hline Pair 7 & $\mid \begin{array}{l}\text { Helps to Engage to solve the difficult tasks Before } \\
\text { Helps to Engage to solve the difficult tasks After }\end{array}$ & -2.600 & .894 & .163 & -2.934 & \begin{tabular}{l|l}
4 & -2.266
\end{tabular} & -15.922 & 29 & .000 \\
\hline Pair 8 & $\begin{array}{l}\text { Exploring new concept in depth Before } \\
\text { Exploring new concepts in depth After }\end{array}$ & -2.500 & 1.042 & .190 & -2.889 & \begin{tabular}{l|l|}
9 & -2.111
\end{tabular} & -13.138 & 29 & .000 \\
\hline
\end{tabular}


The result shows the P value (.000), which is less than .05 (table value 1.96). So we reject the H4o and accept the H4a. This shows that new media technologies increase student performance in the classroom. It shows that before using the flipped classroom, students were not satisfied as the learning was more monotonous but after using flipped classroom students felt that effective communication with faculty, the teamwork with others, easy to understand the subject, engaging and collaborating with other members were considerably increased.

After the experimentation, the examination of assigned topics was conducted by the teachers and teachers found the marks of students were increased after using the flipped learning in their classroom teaching. The following table shows the improve performance of the students.

Table 5 Marks of the students before/after using flipped classroom

\begin{tabular}{|c|c|c|c|}
\hline \multicolumn{2}{|c|}{ RANGE OF MARKS } & $\mathbf{N}$ & \% \\
\hline \multirow{2}{*}{ 0-5 Marks } & Before & 0 & 0 \\
\cline { 2 - 4 } & After & 0 & 0 \\
\hline \multirow{2}{*}{$5-10$ Marks } & Before & 12 & 40.0 \\
\cline { 2 - 4 } & After & 1 & 3.3 \\
\hline \multirow{2}{*}{$10-15$ Marks } & Before & 16 & 53.3 \\
\cline { 2 - 4 } & After & 13 & 43.3 \\
\hline \multirow{2}{*}{$15-20$ Marks } & Before & 2 & 6.7 \\
\cline { 2 - 4 } & After & 16 & 53.3 \\
\hline
\end{tabular}

As per table 5, it was observed that the majority of students have improved the marks after the implementation of the flipped leaning in the classroom teaching. The students who were scoring 5-10 marks before has scored considerably less than after the implementation of the technology. It was observed that $53.3 \%$ students have scored in the range of 15-20 Marks compared to $6.7 \%$ students before implementation.

Table 6 Paired Sample T-Test on the marks of the undergraduate students of Faculty of Design before and after implementation of flipped learning in the classroom teaching.

\begin{tabular}{|c|c|c|c|c|c|c|c|c|c|}
\hline \multirow{4}{*}{ Pair 1} & \multicolumn{9}{|c|}{ Paired Samples Statistics \& Correlation } \\
\hline & \multirow{3}{*}{\multicolumn{2}{|c|}{$\begin{array}{l}\text { Marks of Students Before using flipped learning } \\
\text { Marks of Students After using flipped learning }\end{array}$}} & Mean & D & \begin{tabular}{c|} 
Std. \\
Deviation
\end{tabular} & $\begin{array}{l}\text { Std. Error } \\
\text { Mean }\end{array}$ & \multicolumn{2}{|c|}{ Correlation } & nig. \\
\hline & & & & & & & \multirow{2}{*}{\multicolumn{2}{|c|}{.497}} & \multirow{2}{*}{.005} \\
\hline & & & 3.50 & 30 & .572 & .104 & & & \\
\hline \multicolumn{10}{|c|}{ Paired Samples Test } \\
\hline \multicolumn{7}{|c|}{ Paired Differences } & \multirow{3}{*}{$\mathbf{t}$} & \multirow{3}{*}{ df } & \multirow{3}{*}{$\begin{array}{l}\text { Sig. (2- } \\
\text { tailed) }\end{array}$} \\
\hline \multirow[b]{3}{*}{ Pair 1} & \multirow[b]{3}{*}{$\begin{array}{l}\text { Marks Range for Students Before } \\
\text { Using Flipped learning } \\
\text { Marks Range for Students After Using } \\
\text { Flipped learning }\end{array}$} & \multirow[t]{2}{*}{ Mean } & \multirow[t]{2}{*}{$\begin{array}{c}\text { Std. } \\
\text { Deviation }\end{array}$} & \multirow{2}{*}{$\begin{array}{l}\text { Std. } \\
\text { Error } \\
\text { Mean }\end{array}$} & \multicolumn{2}{|c|}{$\begin{array}{c}95 \% \text { Confidence } \\
\text { Interval of the } \\
\text { Difference }\end{array}$} & & & \\
\hline & & & & & n $\mid$ Lower & Upper & & & \\
\hline & & -.833 & .592 & .108 & -1.054 & -.612 & -7.709 & 29 & .000 \\
\hline
\end{tabular}


The result shows the $p<0.001$ (table value 1.96, $\mathrm{df}-1,29$ ). So we reject the Ho and accept the Ha. This shows that use of flipped learning had increased student marks in the classroom. It shows that before using the flipped learning students' marks were less and after using flipped learning the marks of the students have considerably increased. The mean value was 3.50 after using the flipped learning.

\section{Conclusion}

It was observed that flipped learning is one of the greatest asset to the present day teaching. It was also observed that the challenges persist with the teachers are overloaded with the extra work as they have to make the videos, share the videos and analyse the outcome of the videos. Students have improved in the marks and also enhanced their performance. The use of the flipped classroom is one of the most emerging new media technology in the university.

\section{References}

Clyde, F. H. \& Nancy A. S. (2013). Case Studies and the Flipped learning. Journal of College Science Teaching, 42(5), $62-66$.

Fulton, K. (2012). Upside down and inside out: Flip your classroom to improve student learning. Learning \& Leading with Technology, 39(8), 12-17.

Jessica, Y., Kari, M., Katherine, M. \& Pakrick, M. Extensive of a review of flipped learning. Flipped learning network. Report, $1-20$.

Neil Aronson, K. M. (2013). Flipped learning in Higher Education. Retrieved from www.pearsonPD.com.

Schwartz, M. (2013). The flipped learning. Learning \& Teaching Office. 1 -3.

Shi-Chun D.U., Ze-Tian F.U., Yi W. (2014). The Flipped learning-Advantages and Challenges. Proceedings of International Conference on Economic Management and Trade Cooperation (p. 17 -20).

Zhao, Y., \& Ho, A. D. (2014). Evaluating the flipped learning in an undergraduate history course. Harvard Graduate School of Education. 2-48. 